\title{
FACEBOOK AS A DIALOGIC COMMUNICATION TOOL AT THE MOST VISITED MUSEUMS OF THE WORLD
}

\section{Facebook como aplicación dialógica en los museos más visitados del mundo}

Paul Capriotti and José-Carlos Losada-Díaz

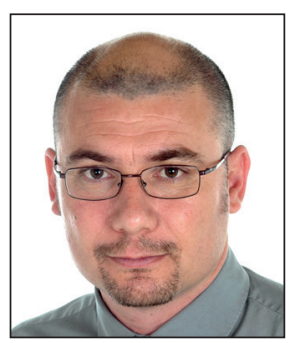

Paul Capriotti has a PhD in Communication by the Universidad Autónoma de Barcelona (Spain). $\mathrm{He}$ is a professor of Public Relations and Corporate Communication at Universidad Rovira i Virgili (Tarragona, Spain). He has published in journals like Public relations review, International journal of information management, Business \& society and Corporate communications. He is the author of 2 books: Planificación estratégica de la imagen corporativa (1999) and Branding corporativo (2009). He is a guest professor at several Spanish and Latin-American universities. http://orcid.org/0000-0002-9398-5886

Universitat Rovira i Virgili Departament d'Estudis de Comunicació Av. Catalunya, 35, 3r piso. 43002 Tarragona, Spain paul.capriotti@urv.cat

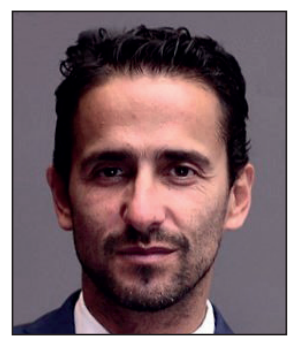

José-Carlos Losada-Díaz, PhD in Communication by the Universidad Pontificia de Salamanca (UPSA), is a professor of the Department of Communication at the Universidad de Murcia (Spain), where he teaches Institutional and Corporate Communication. He is also a postgraduate professor in more than twenty universities in Spain and Latin America. He works in corporate communication and branding. His publications include Gestión de la Comunicación en las Organizaciones (2004), Comunicación en la gestión de crisis: lecciones prácticas (2010) and (No)crisis (2018). http://orcid.org/0000-0002-3966-837X

Universidad de Murcia Facultad de Comunicación y Documentación Campus Universitario de Espinardo. 30100 Murcia, Spain jclosada@um.es

\begin{abstract}
Social networks have obtained a relevant presence in Communication programs and they are changing the way to disseminate information and engage in dialogue. They permit a more balanced and participatory model of communication between publics and organizations, based in dialogue and conversation, not persuasion. The main objective of this paper is to evaluate how museums are using Facebook to interact and engage in dialogue with their publics. This work asks if they are using this platform in order to be recognized as 'museums 2.0'. Our results illustrate that the museums we studied (the 100 which are most important on the global level) have a very poor activity on Facebook, and they are not using all the opportunities that this social network offers as an interactive and dialogical means of communication.
\end{abstract}

\section{Keywords}

Museums; Corporate communication; Dialogic communication; Social networks; Facebook; Museum 2.0; Interaction.

\section{Resumen}

Las redes sociales han alcanzado una presencia relevante en los programas de comunicación y están cambiando la forma de difundir información y dialogar entre públicos y organizaciones. Permiten un modelo más equilibrado y participativo de comunicación, basado en el diálogo y la conversación, no en la persuasión. El objetivo principal de este trabajo es evaluar cómo los museos utilizan Facebook para interactuar y dialogar con sus públicos. Este trabajo analiza si están utilizando esta plataforma para ser reconocidos como 'museos 2.0'. los resultados indican que los museos que se han estudiado (los 100 más importantes a nivel global) tienen una actividad muy pobre en Facebook y no aprovechan todas las oportunidades que ofrece esta red social como medio interactivo y dialógico de comunicación.

\section{Palabras clave}

Museos; Comunicación corporativa; Comunicación dialógica; Redes sociales; Facebook; Museos 2.0; Interacción. 


\section{Introduction}

In the last decade, digital communication has been established as an indispensable tool in the communication strategies of all kinds of organizations. It has very rapidly altered the ecosystem, conditions, tools and communication capabilities of any organization. Its relative weight has increased such that some authors even claim that are changing the form of communicating. Zerfass et al. (2014) indicate that the results of the European Communication Monitor 2014 clearly illustrate this transfer from conventional to digital communication, highlighting the fact that the trend in strategic communication shows that its online dimension is clearly leading the list of the main tools and channels for communication. Moreover, again citing the European Communication Monitor 2014 (Moreno et al., 2015), the prospects for the immediate future indicate that social networks will increase their presence as a communication tool in organizations significantly in the coming years.

\section{Social networks have reached a relevant presence in communication programs}

Digital communication is also playing an increasingly important role in museums as part of the new configuration of these institutions and the need to build organizations that go beyond the walls of their buildings and have a better connection with citizens (Hooper-Greenhill, 2000; Gurel; Kavak, 2010; Allen-Greil; MacArthur, 2010; Gómez-Vílchez, 2012; Martínez-Sanz, 2012; Capriotti, 2013). For a long time, the resources of the (essentially unidirectional) web 1.0 expanded the capacity of these institutions to disseminate information in a way that was large scale, controlled, fast and easy (Marty, 2007; Tallon; Walker, 2008; Capriotti, 2011) and enabled museums provide information in a "up-down" strategy (Capriotti; Pardo-Kuklinski, 2012; Viñarás-Abad; Cabezuelo-Lorenzo, 2012; Claes; Deltell, 2014).

However, the social web, and specifically social networking, favors a more participatory model and balanced communication between organization and publics, based on dialogue and conversation, not persuasion. Several authors (Sweetser; Lariscy, 2008; Schulte, 2009; Waters et al., 2009; Padilla-Meléndez; Del-Águila-Obra, 2013; Kim; Kim; Hoon-Sung, 2014) argue that the communication in social networks is based on two key aspects: first, disseminating their own content through the constant updating of their spaces in social media. And second, the generation and maintenance of a dialogue and interaction with their publics through these platforms. Social media involves a substantial change in the way they relate to the different publics of the organization, in a much more direct and reciprocal manner. As Sevick-Botree \& Seltzer (2009) state, social networks provide organizations with a space to interact with their key publics, and also enable network users interact with other users on topics of mutual interest, thus establishing the ideal conditions to stimulate dialogic communication.

The social web and the 2.0 tools (more collaborative, multidirectional and dialogic) are offering museums new options and possibilities of communication and changing the way in which museums engage with their publics based on the active involvement and participation of the user. This allows the exchange of information, debate, discussion and collaboration (Crenn; Vidal, 2007; Lopez et al., 2010; Kidd, 2011; Viñarás-Abad; Cabezuelo-Lorenzo, 2012; Claes; Deltell, 2014), and contributes to create more participative channels of communication for this type of institutions (Lopez et al., 2010; Martínez-Sanz, 2012; Cordón-Benito; González-González, 2016). This explains why these platforms have become frequently applied in the communication strategies of museums (Marty, 2007; Simon, 2010; Capriotti; Pardo-Kuklinski, 2012; Cabrera-Bravo; Cabrejas-Almena, 2013).

Thus, social networks make tangible a new conception of museums, going beyond the walls that limit them and expanding the capacity to influence of these organizations. Simon (2010) defines what is known as the 'Museum 2.0' (or Social museum) as one that seeks to expand the visitor experience beyond the physical space to become a platform for the creation, discussion and negotiation between the institution, artists and visitors. In this new conception of museums (Srinivasan et al., 2009), social networks are tools that can help expand and stimulate dialogue on museum activities (Kidd, 2011), which is a clear manifestation of the Museum 2.0.

Although such museums are still in an embryonic stage (Lopez et al., 2010; Capriotti; Pardo-Kuklinski, 2012; Padilla-Meléndez; Del-Águila-Obra, 2013), one can observe a growing need for the museum to establish conversations with the virtual visitors and actively participate in discussions not generated by the organization (Cabrera-Bravo; Cabrejas-Almena, 2013; Caerols-Mateo; Viñarás-Abad; Gonzálvez-Valles, 2016). That is to say, as Holdgaard (2011) notes, through social networks, online communication of the museums can be much more active, participatory and dialogic than their traditional communication.

In this context, organizations like museums find in Facebook an essential instrument of relating to their publics, based on interaction, active listening and participation (Sweetser; Lariscy, 2008; Kim; Kim; Hoon-Sung, 2014). The ability of Facebook to allow and encourage interaction between the organization and its different publics can go beyond the usual functions of dissemination of information, to a much more comprehensive, broad and diverse communication that allows organizations to develop, cultivate and maintain dialogic communication with their key publics. 
Facebook has been established as a key tool for museums, for its ability to be configured as a useful platform to facilitate dialogue between the museum's organization and its publics (Viñarás-Abad; Cabezuelo-Lorenzo, 2012), and the fact that it allows them to go beyond the usual broadcast functions to a much more comprehensive scenario, expanding the capacity for participatory communication of museums and even creating more open and active spaces.

The aim of this paper is to analyze whether Facebook is used by museums as a tool for dialogic communication with their publics, evaluating the activities carried out and the use of the various resources available to encourage interaction with their publics through this social platform. To do this, the top 100 art museums worldwide will be studied, which allows a large sample of the use of Facebook in 24 countries divided into 3 main geographical areas: Europe, America and Asia/ Pacific.

\section{Methodology}

The object of this study has been the major art museums worldwide. To define the sample we used the number of annual visits to museums, and chose to analyze the most visited art museums. The sample was collected from annual ranking of visits by the prestigious magazine The art newspaper, which annually publishes a list of the most visited museums in the world of art.

http://www.theartnewspaper.com

\section{Facebook facilitates museums to engage in dialogue with their publics}

To prevent some institutions which have recently appeared in the limelight, the rankings produced for five years (from 2008 to 2012, published from 2009 to 2013) were compared, and museums that appeared at least three times in the five years analyzed were selected, or in two of the last three years (2010-2012). The final sample included 100 museums from 24 countries: 60 from Europe, 23 from America, 17 from Asia/Pacific.

We analyzed the Facebook page identified as the "official account" of each museum. This was located by tracking the most popular Internet search engine, and also the Facebook's own search function.

The unit of analysis was the published posts on the Facebook pages of selected museums. All posts published during alternate weeks of each month (even weeks) for 12 months ( 1 year full) were chosen. In total, 26 weeks of analysis, including two weeks at two key dates related to museums at international level: the "International museums day" (on $18^{\text {th }}$ May) and the "Ask a curator" day (on $17^{\text {th }}$ September).

To achieve the objective set in this study, three research questions were established, in relation to three basic aspects linked to the use of Facebook. These were the "Posting activity", the "Posting resources" and "Interaction resources" of each museum.

RQ1: What levels of activity do museums have on Facebook? (Posting activity).

RQ2: What types of resources are used to publish their content? (Posting resources).

RQ3: Do the Facebook pages of the museums contain tools to facilitate and promote interaction and dialogue with visitors? (Interaction resources).

Taylor \& Kent (2014) indicate that dialogic communication is the framework for the building of relationships between an organization and its publics through the Internet. Dialogic communication can be defined as

"an ongoing interaction between organizations and their publics using Internet tools, which enables information, comments, opinions, assessment and experiences to be exchanged on a continuous basis" (Capriotti; Pardo-Kuklinski, 2012, p. 620).

In this way, the type of resources (RQ2) and the interaction tools (RQ3) used on Facebook open up new possibilities for dialogue between organizations and their publics, since social networks expand the potential for and provide new possibilities for organizations to promote dialogic communication (Viñarás-Abad; Cabezuelo-Lorenzo, 2013; Guillory; Sundar, 2014; Capriotti; Carretón; Castillo, 2016; Caerols-Mateo; Viñarás-Abad; Gonzálvez-Valles, 2016; Cordón-Benito; González-González, 2016). 
Table 1. Posting frequency on Facebook

\begin{tabular}{|l|}
\hline Less than 1 post per week (quasi inactive) \\
\hline Between 1 and 4 posts per week (very low) \\
\hline Between 4 and 7 posts per week (low) \\
\hline Between 7 and 10 posts per week (adequate) \\
\hline Between 10 and 15 posts per week (high) \\
\hline More than 15 posts per week (very high) \\
\hline
\end{tabular}

Regarding RQ1, the category of "Posting activity" was developed. The 'Activity' element indicates the volume and frequency of publications or update posts on the page. Based on various studies (Patel, 2016; Jordan, 2017; McLean, 2017), there were established several levels of Frequency of posting (Table 1). According to these reports, the adequate frequency of posting would be between 1 and 2 posts per day (around 7 and 15 posts per week).

For RQ2, the 'Posting resources' element (Table 2) allows us to analyze how the museums are integrating different kind of resources or tools to post their information, since Facebook lets the sender use and combine several formats (such as text, images, audio, video, links, hashtags, etc.). Three types of resources were identified. The first type was classified as "Graphic" (this includes plain texts and fixed images, photos and figures). The second type of resources was defined as "Audiovisual" (including audio and video tools). The third type was named as "Interactive", which includes resources like 'links', 'hashtags' and 'users quoted' (with the @name method).

For the RQ3 the category of "Interaction resources" (Table 3) was developed, which allows us to evaluate the tools and resources available for promoting interaction with the contents published on the museum's pages, and to assess the readiness for dialogue with virtual visitors. For this, four main aspects are established for analysis:

1) "Viralization": analysis of reproduction and propagation by virtual visitors of the information released by the museum, through two sources: the 'likes' (volume of likes obtained by each publication) and 'shares' (number of times a post was shared).

Table 3. Interaction resources on Facebook

\begin{tabular}{|c|c|c|}
\hline Category & Types of resources & Tools \\
\hline \multirow{8}{*}{$\begin{array}{l}\text { Interaction } \\
\text { resources }\end{array}$} & \multirow{2}{*}{ Viralization } & No of likes \\
\hline & & $\mathrm{N}^{\circ}$ of shares \\
\hline & \multirow{4}{*}{ Type of Interaction } & $\begin{array}{l}\text { Only dissemination of infor- } \\
\text { mation }\end{array}$ \\
\hline & & Call to share \\
\hline & & Call to give opinion \\
\hline & & Call to action \\
\hline & \multirow{2}{*}{ Conversation } & $\begin{array}{l}N^{\circ} \text { of visitor comments to muse- } \\
\text { um posts }\end{array}$ \\
\hline & & $\begin{array}{l}N^{\circ} \text { of museum comments to } \\
\text { visitor comments }\end{array}$ \\
\hline
\end{tabular}

Table 2. Types of resources on Facebook

\begin{tabular}{|c|c|c|}
\hline Category & Types of resources & Tools \\
\hline \multirow{7}{*}{ Types of resources } & \multirow{2}{*}{ Graphic } & Texts \\
\hline & & Photos/Images/Figures \\
\hline & \multirow{2}{*}{ Audiovisual } & Audio \\
\hline & & Video \\
\hline & \multirow{3}{*}{ Interactive } & Links \\
\hline & & Hashtags \\
\hline & & Quoted users \\
\hline
\end{tabular}

2) "Type of interaction", which assesses the action that is fostered through the publication of the contents. This has four options: 'just dissemination of information' (only aims to present and disseminate the contents), 'call to share' (encouraging visitors to share information with other users on the same network or other networks, including expressions that encourage sharing the post), 'call to give an opinion' (the use of words or expressions that encourage giving or expressing opinion or commenting by virtual visitors) and 'call to action', which encourages users to participate or collaborate with comments that drive actions (encouraging users to suggest ideas, go to the museum, subscribe to an activity, etc.).

3) "Conversation": analysis of the 'comments' that are made on the posts made by the museum on its Facebook page, either by users on the posts of the museum or comments made by the museum in response to the comments of virtual visitors.

After defining the template for analysis, a test was performed on 20 Facebook pages to test the suitability of the template. After making the necessary adjustments, a content analysis was made to evaluate all posts collected during the designated time period. The data obtained were processed using SPSS for the results presented below.

\section{Results}

A total of 5,376 posts were obtained. The results were organized according to the established research questions.

\subsection{Posting activity of museums on Facebook}

Regarding the 'Activity level' on Facebook, an analysis was made based on the number of posts that the museum makes on its fanpage. Museums have a low average of just over two posts per week (Table 4). That is, these organizations spend an average of more than three days creating each publication. Moreover, the average number of original posts of museums is even smaller, with 1.72 weekly publications.

Table 4. Activity of museums on Facebook

\begin{tabular}{|l|c|c|c|c|}
\hline \multicolumn{1}{|c|}{ Activity } & N & \% & $\begin{array}{c}\text { Media per } \\
\text { museum }\end{array}$ & $\begin{array}{c}\text { Media per museum } \\
\text { per week }\end{array}$ \\
\hline Original posts & 4,172 & 77.6 & 44.9 & 1.72 \\
\hline Shared posts & 1,204 & 22.4 & 12.9 & 0.50 \\
\hline Total & 5,376 & 100 & 57.8 & 2.22 \\
\hline
\end{tabular}


Table 5. Publication frequency of museums on Facebook

\begin{tabular}{|l|c|c|}
\hline \multicolumn{1}{|c|}{ Publication frequency } & N & \% \\
\hline Less than 1 post per week (quasi inactive) & 42 & 45.2 \\
\hline Between 1 and 4 posts per week (very low) & 32 & 34.4 \\
\hline Between 4 and 7 posts per week (low) & 15 & 16.1 \\
\hline Between 7 and 10 posts per week (adequate) & 0 & 0.0 \\
\hline Between 10 and 15 posts per week (high) & 4 & 4.3 \\
\hline More than 15 posts per week (very high) & 0 & 0.0 \\
\hline Total & 93 & 100 \\
\hline
\end{tabular}

If we delve into the frequency of publication of posts (Table 5 ), we find that almost half of the museums (45\%) have a quasi inactive account, publishing under a post per week, and more than $90 \%$ of the museums analyzed published less than seven weekly posts.

The majority of art museums worldwide have very poor posting activity on Facebook

Only a residual number of museums (just over $4 \%$ ) have daily activity on their fanpage, publishing around 1.5 posts daily, that is, they are doing an adequate level of posting. These figures indicate that the activity of museums on Facebook is scarce and hardly produces information in a stable manner. Very few museums (less than 5\%) post continuously, i.e., they have a regular activity on Facebook (more than 7 times a week).

\subsection{Posting resources used by museums on Facebook}

Next we shall investigate 'Types of resources'. Given the possibilities for social networks to publish their content across multiple formats and resources, research intended to ascertain which of these were actually being used in posts. As shown in Table 6, the museums use a majority of 'Graphic resources' for the presentation of information on their Facebook pages: almost all the posts include text $(98.8 \%)$ and to a lesser extent the still image or photograph (82.3\%). 'Audiovisual resources' have an almost nonexistent presence (2.8\%). And 'Interactive resources' are used in a very different way: links (70\%) are frequently used, but less than $10 \%$ of the total posts include more specific social networking formats like hashtags (6.6\%) or mentions using the "@user" format $(7.1 \%)$. That is to say, that the museums are not taking advantage of the many resources that social networking and current technology provide and instead focus on using more traditional resources such as text and accompanying images and to a lesser extent, links.
Table 6. Types of resources

\begin{tabular}{|l|l|l|l|}
\hline \multirow{2}{*}{ Types of resources } & \multicolumn{1}{|c|}{ Tools } & \multicolumn{1}{c|}{ N } & \multicolumn{1}{c|}{$\%$} \\
\hline \multirow{2}{*}{ Graphic } & Texts & 5,310 & 98.8 \\
\cline { 2 - 4 } & Photos/images/figures & 4,424 & 82.3 \\
\hline \multirow{3}{*}{ Interactive } & Audio-video & 150 & 2.8 \\
\hline & Links & 3,764 & 70.0 \\
\cline { 2 - 4 } & Hashtags & 356 & 6.6 \\
\cline { 2 - 4 } & Quoted users & 385 & 7.2 \\
\hline
\end{tabular}

\subsection{Interaction resources of museums on Facebook}

The results obtained in the four aspects studied (Viralization, Type of interaction, Conversation and Active listening) indicate little interactive and dialogic use of Facebook pages by museums.

A significant result in this analysis is undoubtedly that of ' $\mathrm{Vi}$ ralization' of the posts of museums on Facebook (Table 7). The data show that each post published on fanpages gets a very high average number of likes (just over 300 likes per post), showing the high level of interest of virtual visitors in the content and activities of the museums. Moreover, each post that is published by museums is shared an average of nearly 80 times, reinforcing the idea that the content posted by museums are of great interest to virtual visitors and showing the great capacity for virtual dissemination of the content posted on this network by the museums.

Table 7. Viralization

\begin{tabular}{|l|c|}
\hline \multicolumn{1}{|c|}{ Viralization } & No \\
\hline Likes per post & 309.2 \\
\hline Shares per post & 78.3 \\
\hline
\end{tabular}

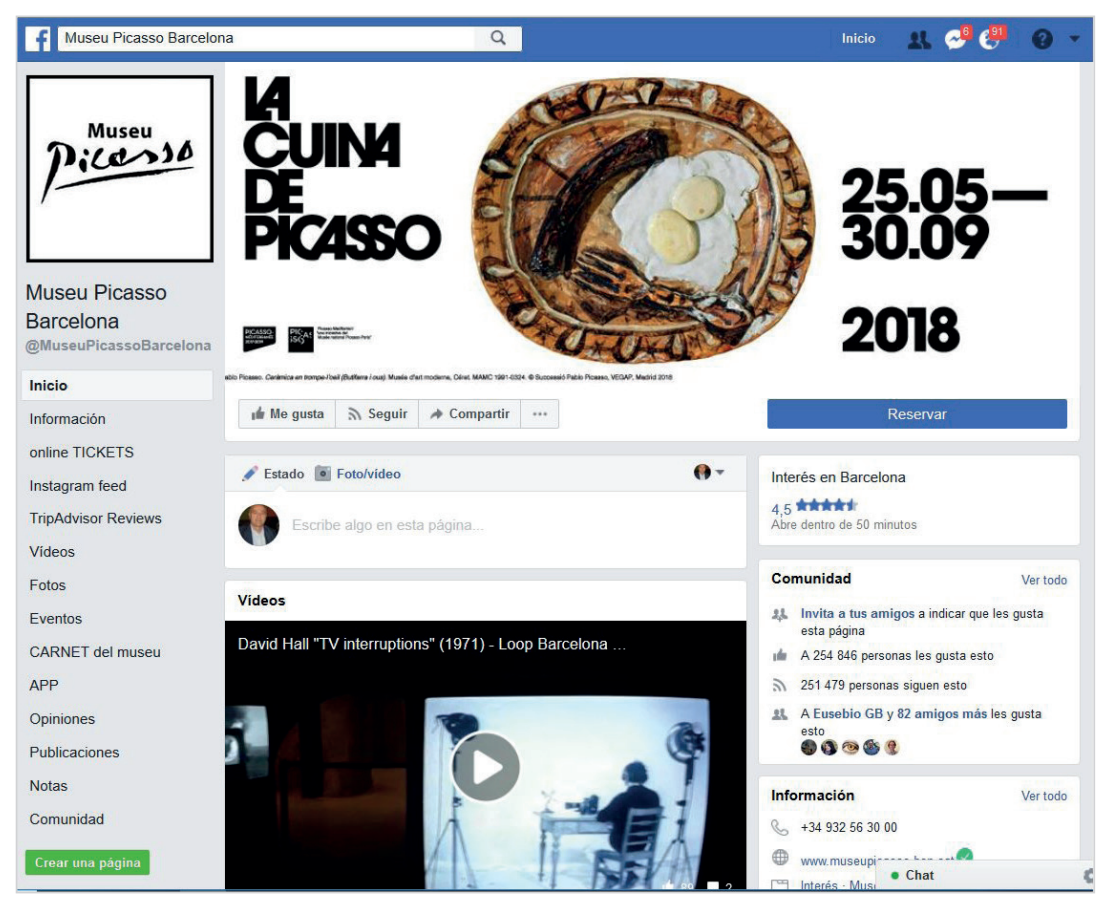

https://www.facebook.com/MuseuPicassoBarcelona 
Table 8. Type of interaction encouraged

\begin{tabular}{|l|c|c|}
\hline \multicolumn{1}{|c|}{ Type of interaction } & N & \% \\
\hline Only dissemination of information & 5,149 & 95.8 \\
\hline Call to share & 0 & 0.0 \\
\hline Call to opinion & 165 & 3.1 \\
\hline Call to action & 62 & 1.1 \\
\hline
\end{tabular}

In relation to the 'Type of interaction' that is encouraged through Facebook, the research suggests a division into four options on a Facebook page, beginning with the least interactive option (the mere "Dissemination of information", without proposing any interaction in the post). This is followed by the "Call to share" (encouraging users to share content on Facebook or other networks) and the "Call to opinion" (encouraging users to comment, rate, etc.). And finally with the "Call to action" (which invites users to suggest an idea, play games, sign up or subscribe, to propose an activity, event, etc.). The results obtained (Table 8 ) are very revealing: $96 \%$ of the posts of museums made use of the first type (a mere dissemination of information) without stimulating the interaction of virtual visitors (through sharing, reviewing or participating) with a clear lack of interest for the possibilities for feedback offered by Facebook. Just $4 \%$ of posts of museums seek to promote sharing, opinion or action on the part of users, by including words, phrases or comments that suggest an interaction. This suggests a very limited and unidirectional use of their presence on Facebook.

Our analysis of the 'Conversation' developed on Facebook aims to quantify and evaluate the conversation stimulated from the museum as well as from users. That is, the possibility that, from the published posts, a dialogue between the virtual visitors and the museum is established through the comments posted. In this regard, the total data (Table 9)
Table 9. Conversation

\begin{tabular}{|l|c|}
\hline \multicolumn{1}{|c|}{ Conversation } & N \\
\hline Museum comments per post per museum & 0.2 \\
\hline User comments per post per museum & 10.0 \\
\hline
\end{tabular}

show that the average is more than 10 comments (10.2) for each post, nearly all (10) written by the internet users and a small percentage $(0.2)$ written by the Museum. This indicates the interest of users in generating dialogue based on the information published by the museums. But it also shows that museums have very little interest in continuing the conversation that they themselves have generated through their fanpages, and simply let the conversation occur between the users themselves. It therefore is an "unreal" conversation due to the fact that the institution ignores the conversation with their virtual visitors and complies only with its role as a disseminator of information.

\section{Museums worldwide are not interacting and engaging in dialogue with their pu- blics}

\section{Conclusions}

Social networks have become a key tool in the communication strategies of all kinds of organizations, providing an unprecedented ability for interaction and dialogue with their publics. The results of our research show, in general, that the museums analyzed (the 100 major museums worldwide) are not taking advantage of all the tools offered by Facebook as a means of interactive and dialogic communication.

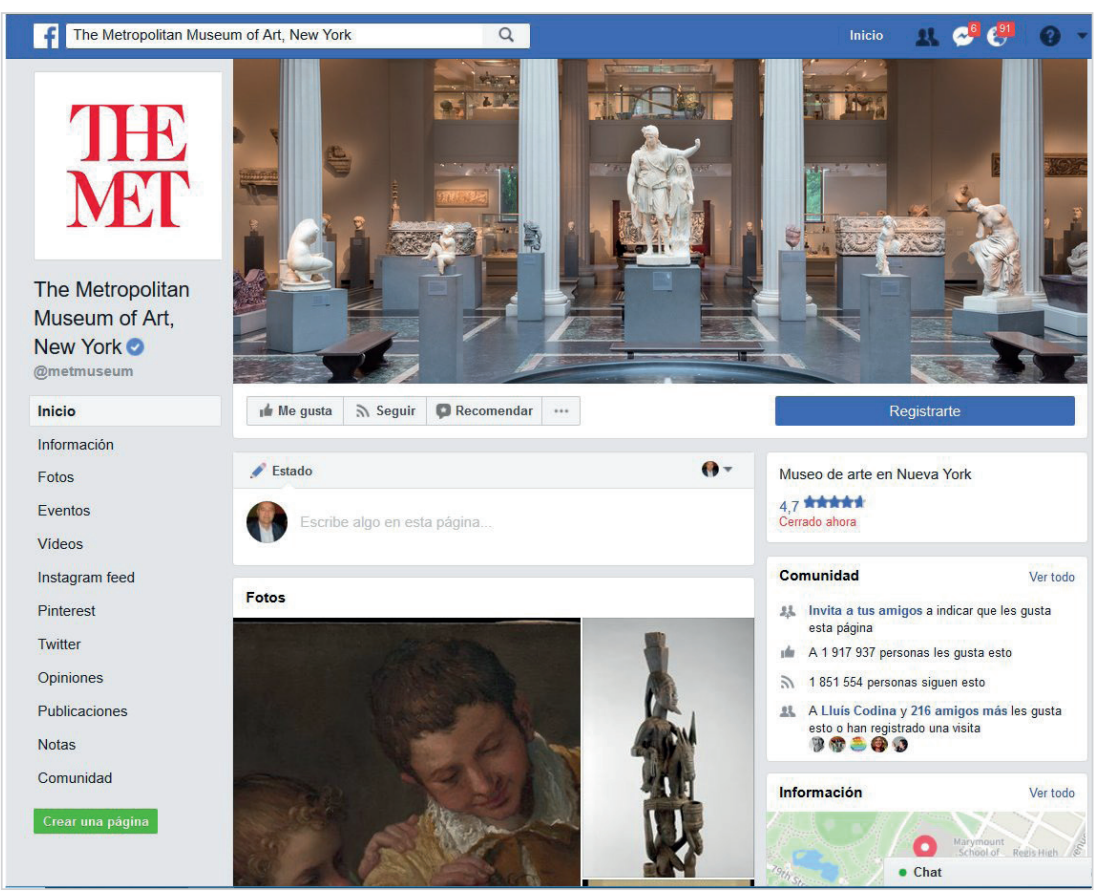

https://www.facebook.com/metmuseum
Regarding the RQ1 (Posting activity), it is observed that the "level of activity" of museums in Facebook is very low, since the average of updates is scarce (about $70 \%$ of the museums published less than 2 posts a week) and only a small group of institutions have daily activity on the social network. So, despite having a strong presence on Facebook, museums do not intensively use this platform to communicate with their virtual visitors.

About the "Types of resources" most used by museums (RQ2), the results indicate a majority use of graphic resources (text and images/photos) and links to their posts on their Facebook pages, while other audiovisual and interactive resources have a very limited presence. That is to say, the museums are prioritizing the use of highly unidirectional/ monologic resources to present their information (focusing on the use of traditional resources) and are not taking 
advantage of the many resources and interactive reporting capabilities available on Facebook.

In the category of "Resources for Interaction" (RQ3), the results indicate little interactive and dialogic use of Facebook by museums, through the evaluation of the three aspects analyzed (Viralization, Type of interaction and Conversation). On the one hand, Internet users show a great interest in the information disseminated by museums and share and converse about the information (with a high volume of 'Viralization' of and 'Conversation' about the posts). However, museums do not promote participation and dialogue, the 'type of interaction' being promoted in fanpages is mostly the mere dissemination of information, and the share, opinion and actions of digital users are not solicited. This is a clear waste of the interaction possibilities of Facebook. To this, we must add that very few museums will establish a 'conversation' with virtual visitors in relation to the posted content (only $0.2 \%$ of the comments associated with the post of museums belong to themselves). That is, the museums do not show much interest in continuing the conversations that they themselves have generated from the information published on fanpages.

This leads us to conclude that museums do not take full advantage of Facebook's dialogic capabilities. Museums are not currently using all the opportunities provided by Facebook in order to proactively interact with their publics. Facebook pages of the museums studied are currently essentially one-way communication tools. Overwhelmingly, museums are still at an early evolutionary stage of interaction and dialogue, listening very little to their publics on the internet and prioritizing the production and dissemination of information in their own self-interest. However, signs can be observed that may presuppose a willingness to improve upon the museums' interaction with publics.

Museums, like many other organizations in the corporate world, maintain a traditional off-line one-way perspective on Facebook, considering it as mere tool that can be used to disseminate information about the institution and its activities, but not to stimulate interaction and two-way communication with their publics. This allows us to conclude that the massive use of Facebook by the museums has not implied a change in mentality about the way they interact with their publics. This social network has brought to the museums a new tool to disseminate their own information in an immediate and global way, but it has not substantially altered the way of thinking related to interactivity and dialogue.

In short, despite having a massive presence on Facebook, most museums analyzed are mainly using Facebook as a tool for disseminating information, so they are not taking advantage of their ability to generate a genuine place for dialogue, exchange and conversation, making it possible to design a new museum (the museum 2.0) that allows interactive expansion of the user experience beyond the physical space, and the creation of a true platform for the creation, discussion and negotiation between the institution, artists and visitors beyond the walls of the institution.

\section{Museums are not using the possibilities that Facebook offers as a dialogical com- munication tool}

\section{Contributions, limitations and further research}

This paper contributes to define a model of analysis for dialogic communication through Facebook, by identifying the key aspects, categories and resources that should be taken into account. Having applied it to the specific sector of museums, we have obtained a perspective about how these organizations develop communication with their publics through Facebook. This will also help entities to develop better tools to foster and improve interactive communication with their key publics. However, the results can not be extrapolated directly to other organizations or institutions (such as companies, NGOs or government entities). Thus, a possible future line of work will apply the methodology developed in this research in other studies related to other types of organizations, which can provide further insight on the future challenges for dialogic communication through Facebook.

Finally, during our research work we have identified some aspects to be considered as future areas of study. Future works on digital (dialogic) communications are needed to 
establish the way in which other social media platforms and other web 2.0 resources are being synergistically used by organizations in their dialogic relationship with their publics and, particularly, how those tools are integrated into the existing communication and public relations programs. We believe that these aspects are particularly relevant for organizations since social media are tools that can allow direct two-way communication with their publics. But this requires a clear communication leadership if they are to be implemented successfully, since the essence of web 2.0 requires entities to change their attitude, and decrease unidirectionality and allow interaction, dialogue and participation.

\section{Acknowledgements and research funding}

This paper is part of the R+D competitive project about "The digital communication of the cultural heritage of museums" (CSO2011-25163), granted by the Ministry of Education and Science of Spain.

\section{References}

Allen-Greil, Dana; MacArthur, Matthew (2010). "Small towns and big cities: How museums foster community online". In: Museum and the web 2010: Intl conf for culture and heritage on-line. Proceedings.

http://www.archimuse.com/mw2010/papers/allen-greil/ allen-greil.htmI\#ixzzOzcB2tusc

Cabrera-Bravo, María-Jesús; Cabrejas-Almena, María-Carmen (2013). "Del XIX al XXI: el Museo del Romanticismo en internet". Revista de museología, n. 56, pp. 88-100.

https://www.museologia.net/revista

Caerols-Mateo, Raquel; Viñarás-Abad, Mónica; Gonzálvez-Valles, Juan-Enrique (2017). "Redes sociales y museos: análisis de la campaña en Twitter para el Día internacional de los museos y noche de los museos". Revista latina de comunicación social, n. 72, pp. 220-234.

https://doi.org/10.4185/RLCS-2017-1162

Capriotti, Paul (2011). “Communicating corporate social responsibility through the Internet and social media". In: Ihlen, Oyvind; Bartlett, Jennifer; May, Steve (eds.). The handbook of communication and corporate social responsibility. Boston: Wiley-Blackwell, pp. 358-378.

https://doi.org/10.1002/9781118083246.ch18

Capriotti, Paul (2013). "Managing strategic communication in museums: The case of Catalan museums". Comunicación y sociedad, v. 26, n. 3, pp. 98-116.

https://www.unav.es/fcom/communication-society/en/ resumen.php?art_id $=460$

Capriotti, Paul; Carretón, Carmen; Castillo, Antonio (2016). "Testing the level of interactivity of institutional websites: From museums 1.0 to museums 2.0". International journal of information management, v. 36, n. 1, pp. 97-104.

http://rua.ua.es/dspace/handle/10045/58099

https://doi.org/10.1016/j.ijinfomgt.2015.10.003

Capriotti, Paul; Pardo-Kuklinski, Hugo (2012). “Assessing dialogic communication through the Internet in Spanish museums". Public relations review, v. 38, n. 4, pp. 619-626. https://doi.org/10.1016/j.pubrev.2012.05.005
Claes, Florencia; Deltell, Luis (2014). "Museos sociales. Perfiles museísticos en Twitter y Facebook 2012-2013". El profesional de la información, v. 23, n. 6, pp. 594-602.

https://doi.org/10.3145/epi.2014.nov.06

Cordón-Benito, David; González-González, Diana (2016). “Museos y comunicación: los nuevos medios como herramienta de diálogo y sociabilidad de la institución. El uso de Twitter por el Museo del Prado, Museo Thyssen-Bornemisza y Museo Reina Sofía". Fonseca: Journal of communication, n. 12 , pp. 149-165.

https://doi.org/10.14201/fjc201612149165

Crenn, Gaëlle; Vidal, Geneviève (2007). "Les musées français et leurs publics a l'âge du web 2.0. Nouveaux usages du multimédia et transformations des rapports entre institutions et usagers?". In: International cultural heritage informatics meeting 2007: Proceedings.

http://www.archimuse.com/ichim07/papers/crenn/crenn.html

Gómez-Vílchez, Soledad (2012). “Museos españoles y redes sociales". Telos: cuadernos de comunicación e innovación, $\mathrm{n}$. 90, pp. 79-86.

http://goo.gl/QjqgBj

Guillory, Jamie E.; Sundar, S. Shyam (2014). “How does web site interactivity affect our perceptions of an organization?". Journal of public relations research, v. 26, n. 1, pp. 44-61. https://goo.gl/r1btfu https://doi.org/10.1080/1062726X.2013.795866

Gürel, Eda; Kavak, Bahtisen (2010). “A conceptual model for public relations in museums". European journal of marketing, v. 44, n. 1-2, pp. 42-65.

https://goo.gl/KsWCrR

https://doi.org/10.1108/03090561011008600

Holdgaard, Nanna (2011). "The use of social media in the Danish museum landscape". In: Museums and the web 2011: Proceedings.

https://www.museumsandtheweb.com/mw2011/papers/ the_use_of_social_media_in_the_danish_museum_l

Hooper-Greenhill, Eilean (2000). "Changing values in the art museum: Rethinking communication and learning". International journal of heritage studies, v. 6, n. 1, pp. 9-31. https://doi.org/10.1080/135272500363715

Jordan, Rachel (2017). "How frequently should I post to Facebook?". 929 marketing creative, June 24.

https://www.929marketing.com/blog/how-frequentlyshould-i-post-to-facebook?rq=how\%20frequently

Kidd, Jenny (2011). “Enacting engagement online: Framing social media use for the museum". Information, technology and people, v. 24, n. 1, pp. 64-77.

https://orca.cf.ac.uk/36953/1/itp_kidd_post-review.pdf https://doi.org/10.1108/09593841111109422

Kim, Sora; Kim, Soo-Yeon; Hoon-Sung, Kang (2014). “Fortune 100 companies' Facebook strategies: Corporate ability versus social responsibility". Journal of communication management, v. 18, n. 4, pp. 343-362.

https://doi.org/10.1108/JCOM-01-2012-0006

López, Ximena; Margapoti, Ilaria; Maragliano, Roberto; 
Bove, Giuseppe (2010). "The presence of web 2.0 tools on museum websites: A comparative study between England, France, Spain, Italy, and the USA". Museum management and curatorship, v. 25, n. 2, pp. 235-249.

https://goo.gl/FwZJHa https://doi.org/10.1080/09647771003737356

Martínez-Sanz, Raquel (2012). "Estrategia comunicativa digital en el museo". El profesional de la información, v. 21, n. 4, pp. 391-395.

https://doi.org/10.3145/epi.2012.jul.10

Marty, Paul (2007). "Museum websites and museum visitors: Before and after the museum visit". Museum management and curatorship, v. 22, n. 4, pp. 337-360.

http://marty.cci.fsu.edu/preprints/marty_mmc2008.pdf https://doi.org/10.1080/09647770701757708

McClean, Roy (2017). "How often should you post on social media?". Customfitonline. Making the web work for you, January 10.

https://www.customfitonline.com/news/2017/1/10/howoften-should-you-post-on-social-media

Moreno, Ángeles; Navarro, Cristina; Tench, Ralph; Zerfass, Ansgar (2015). "Does social media usage matter? An analysis of online practices and digital media perceptions of communication practitioners in Europe". Public relations review, n. 41, pp. 242-253.

https://doi.org/10.1016/j.pubrev.2014.12.006

Padilla-Meléndez, Antonio; Del-Águila-Obra, Ana-Rosa (2013). "Web and social media usage by museums: Online value creation". International journal of information management, v. 33, n. 5, pp. 892-898.

https://goo.gl/AgzfMr

https://doi.org/10.1016/j.ijinfomgt.2013.07.004

Patel, Neil (2016). "How frequently you should post on social media according to the pros". Forbes, September 12. https://www.forbes.com/sites/neilpatel/2016/09/12/howfrequently-you-should-post-on-social-media-according-tothe-pros/\#12bfaf77240f

Schulte, Bret (2009). "The distribution revolution. How news organizations are intensifying their use of social networking venues like Twitter and Facebook to circulate their stories and connect with their communities". American journalism review, v. 31, n. 5, pp. 22-25.

https://goo.gl/sCdtYT

Sevick-Bortree, Denise; Seltzer, Trent (2009). “Dialogic stra- tegies and outcomes: An analysis of environmental advocacy groups' Facebook profiles". Public relations review, v. 35, n. 3, pp. 317-319.

https://goo.gl/zhbueF

https://doi.org/10.1016/j.pubrev.2009.05.002

Simon, Nina (2010). The participatory museum. Santa Cruz (USA): Museum 2.0. ISBN: 9780615346502

http://www.participatorymuseum.org

Srinivasan, Ramesh; Boast, Robin; Furner, Jonathan; Becvar, Katherine (2009). "Digital museums and diverse cultural knowledges: Moving past the traditional catalog". The information society: An international journal, v. 25, n. 4, pp. 265-278.

https://goo.gl/V1zvaa

https://doi.org/10.1080/01972240903028714

Sweetser, Kaye D.; Lariscy, Ruthann W. (2008). “Candidates make good friends: An analysis of candidates' uses of Facebook". International journal of strategic communication, $\mathrm{v}$. 2, n. 3, pp. 175-198.

https://goo.gl/7Yi595

https://doi.org/10.1080/15531180802178687

Tallon, Loic; Walker, Kevin (2008). Digital technologies and the museum experience: Handheld guides and other media. Lanham: Altamira Press. ISBN: 9780759111219

Taylor, Maureen; Kent, Michael (2014). "Dialogic engagement: Clarifying foundational concepts". Journal of public relations research, v. 26, n. 5, pp. 384-398.

https://doi.org/10.1080/1062726X.2014.956106

Viñarás-Abad, Mónica; Cabezuelo-Lorenzo, Francisco (2012). "Claves para la participación y generación de contenido en las redes sociales: estudio de caso del Museo del Prado en Facebook". AdComunica, n. 3, pp. 87-103.

http://www.adcomunicarevista.com/ojs/index.php/ adcomunica/article/view/49/0

Waters, Richard D.; Burnett, Emily; Lamm, Ann; Lucas, Jessica (2009). "Engaging stakeholders through social networking: how nonprofit organizations are using Facebook". Public relations review, v. 35, n. 2, pp. 102-106. https://doi.org/10.1016/j.pubrev.2009.01.006

Zerfass, Ansgar; Tench, Ralph; Verhoeven, Piet; Verčič, Dejan; Moreno, Ángeles (2014). European communication monitor 2014.

http://www.zerfass.de/ECM-WEBSITE/media/ECM2014Results-ChartVersion.pdf

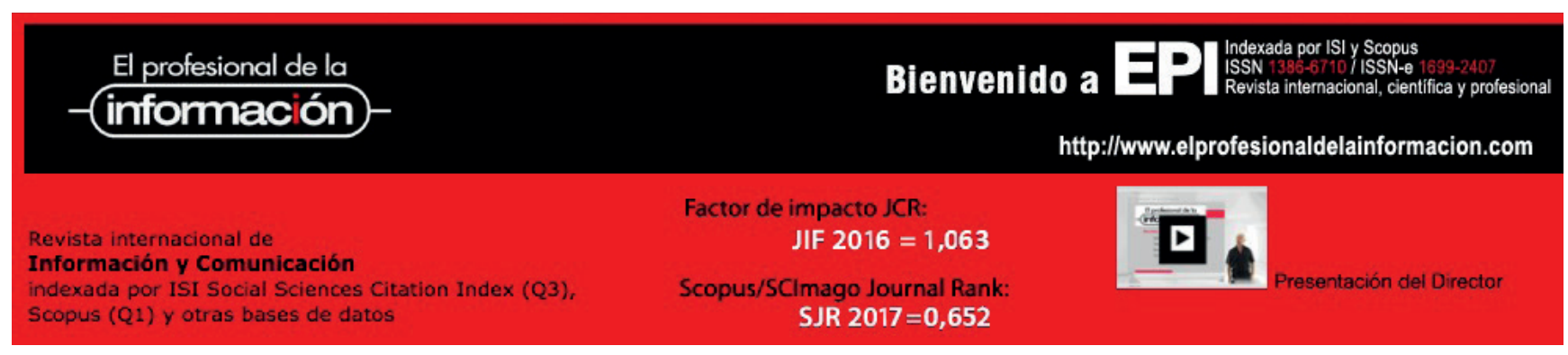

